\title{
Understanding Human Rights from an Eastern Perspective: A Discourse
}

\author{
Ravi Prakash Vyas* and Rachit Murarka**
}

\section{1 \\ Introduction}

Human rights, though assumed as a Western concept, is not an exclusive construct of the Western world. As a matter of fact, if one analyses the rich debate around human rights and the obstacles which Human Rights Commission have overcome to establish certain universal values as rights, ${ }^{1}$ one would not fall into the trap of engaging in an East versus West debate on human rights. There is an overwhelming influence of the West on the discourse around human rights, owing to the World Wars. However, it would be a travesty to conclude that Asian views were not considered while drafting the Universal Declaration of Human Rights. In fact, the drafting committee of Human Rights had two prominent Asian scholars, Charles Malik from Lebanon and P.C. Chang from China. Later, Charles Malik served as a president of the Human Rights Commission.

Despite having a long history of practices which can be equated with the principles of human rights in the Asian region, it is established globally that human rights is largely a Western concept. The misconception lies in the interpretation of Asian texts. Most of the ancient Asian texts are analysed from the lens of religion. Another misconception is that the Judeo-Christian religion is a Western religion, and that Hinduism, Islam and Buddhism are oriental religions. However, the fact of the matter is that all major religions have their roots in Asia. Christianity, though claimed as a Western religion, is rooted in Asia and, from there, spread to the West. Therefore, juxtaposing Christianity as a Western religion against Eastern religions like Hinduism, Buddhism and Islam is a factual error. But it is also true that the West is more influenced by Christianity than any other religions.

\footnotetext{
* Assistant Professor of Public International Law and Human Rights, Kathmandu School of Law, Nepal.

** Assistant Professor of International Relations and Legal Research, Kathmandu School of Law, Nepal.

1 Micheline R. Ishay, The History of Human Rights (2008).
} 
Religion is an integral part of daily life in Eastern societies, and it dictates many facets of lives. Religion provides guidelines for day to day behaviour, and these guidelines are in the form of directives that can be equated with duties. These duties, many scholars claim, are the predecessors of the grammar of human rights. Some scholars also mention that the teachings of Eastern religions could be said to be proto-human rights. ${ }^{2}$ The main emphasis of religion is on the obedience of duties, rather than the realisation of rights. And this is a common thread in all the religions. That is why Subedi claims human rights are universal and found in all great civilisations and religions of the world. ${ }^{3}$ The claims of human rights being the product of Western Christian civilisation have sought to project the selective nineteenth century values during the epitome of colonial domination. ${ }^{4}$ However, we cannot undermine the atrocities experienced in deprivation of such human rights in such phases of time period. ${ }^{5}$ This does not mean that Western civilisation has been reluctant to practice human rights values, but this is to understand that the ideal concept of peaceful coexistence has never existed, and therefore, Asian societies also have had their uncertain period of practice in human rights.

Human rights practice can be found in different parts of Asia since ancient times, if not explicitly using the term 'human rights' itself, then through different customs, norms and practices. The practice delves into the very way of life that people possess. It is closely associated with religious and social conditions and specific history, culture and values of a particular country. However, it is also to understand that we should not compare the human rights concept of such Asian societies with the existing liberal framework. Societies existed in their sphere of autonomy and harmony and coexisted irrespective of their religious differences. ${ }^{6}$ They considered emperor and king as guardian of their nations therefore, it was people's willingness to correspond to an important role and responsibility in the society, and not merely entitlement was forced due to the social hierarchy. Countries at different development stages or with different historical traditions and cultural backgrounds also have a different understanding and practice of human rights. ${ }^{7}$

2 Id.

3 Surya P. Subedi, Are the Principles of Human Rights 'Western' Ideas? An Analysis of the Claim of the 'Asian' Concept of Human Rights from the Perspective of Hinduism, 30 CALIFORNIA Western International LaW Journal 45 (1999).

4 Id.

5 Id.

6 Id.

7 Pieter van Dijk, A Common Standard of Achievement: About Universal Validity and Uniform Interpretation of International Human Rights Norms, 13 NetherLANDS QUARTERLy OF HuMAN Rights 105, 105 (1995) (quoting a speech by Liu Huaqui, the head of the Chinese delegation at the World Conference on Human Rights, Vienna, June 15, 1993). 
The Western civilisation has significantly contributed in formulating human rights notions, and countries around the world have acknowledged the contribution of their effort especially after the Second World War. However, this does not mean that the traditional framework of governing the society and respect of every human being never existed before. The relation of modern and the West has severely disintegrated such values. The division of economy and labour was seen as discrimination even where people seek the highest amount of welfare. In other words, it is unfortunate to correspond that the colonial mission of making societies into consumer market means that values and customs of human rights in societies have disappeared. ${ }^{8}$ This makes us understand that the denial to accept that the concept of human rights existed in Asian societies would be a mindless proposition. ${ }^{9}$

Looking at all the major ancient civilisations, it is found that every one of them had a separate way to protect the safety and dignity of people both in times of war and peace. After outlining a brief survey of human rights history in State practice, Shelton rightly concludes that "[d]ifferent cultures and different legal systems vary in the priorities and emphases given to particular rights, and vary according to traditions and perceived threats. Yet there exist today commonly shared legal norms accepted and recognized by all states". ${ }^{10}$

\section{$2 \quad$ Significance of Human Rights in Eastern Societies}

Expressing the entire custom and human rights norm inclusive in Asian communities is difficult. Due to the existence of wide and unique systems of governance and societal practice, Asian communities highlight the very existence of diversity. Oriental perspective in such a situation tries to express the custom of Asian societies especially in relation to 'cultural enterprises'. It should be clear; this connotation of orientalism in no way should correspond to the discriminatory nature or inferior classification of the orient or orientalism. ${ }^{11}$ The Eastern understanding of human rights differs from the democratic

8 John H. Bodley, Victims of Progress (3rd ed. 199o).

9 Surya P. Subedi, Land and Maritime Zones of Peace in International Law 67-69 (1996).

10 Dinah Shelton, Universal Recognition of Human Rights (1987) (unpublished paper presented at the 18th Study Session of the International Institute of Human Rights in Strasbourg) (on file with author).

11 According to Edward Said, the relationship between the west and the Orient is a relationship of power, of domination, and of varying degrees of a complex hegemony. Hence, the concept of the Orient being inferior in civilizational or value-based terms was created by the West. See EdWard W. Said, Orientalism 5-6 (1978). 
institution and liberal framework. The perspective is more centred on coexistence, and rationality lies on sustainability which is much aligned with the reciprocity rule (i.e., except the treatment from another person on the basis of your treatment of another person). In this concept, the institutions created in the earlier period without having democratic values were suitable in local government in the particular areas. The anarchical rule from some rulers does not overrule the entire cohesion maintained in the historical time frame as suggested from various writings and scriptures from ancient periods. ${ }^{12}$

Another important matter of investigation is that the values related to human rights existed in Asian societies much before the Universal Declaration of Human Rights, but the principles were not seen from the lens of modern human rights. In fact, modern human rights was not conceived out of a vacuum. Modern human rights is like an organism which is evolved out of various set of ideas prevailing at different times. It is influenced by ideas from the Renaissance and the age of enlightenment; at the same time, it also takes into account various religious guidelines. Human rights, like an organism, is still evolving. An interesting point here is that the language of duties in religious texts took the form of rights in the modern world. In fact, the idea of human rights in Asia itself is a product of historical developments that started taking place over hundreds of years ago. For instance, Rene Cassin recognised the natural law and religious foundation of the Universal Declaration of Human Rights. The first article of the Declaration talks about the equality and spirit of brotherhood. This article can be said to have been influenced by the Bible: 'Love thy neighbour as thyself' and 'love the stranger as you love yourself'. 13 Cassin maintained that one should not lose the values of fundamentals, according to him:

[T] he concept of human rights comes from the Bible, from the Old Testament, from the Ten Commandments. Whether these principles were centred on the church, the mosque or the poils, they were often phrased in terms of duties, which now presume rights. For instance, Thou shall not murder is the right to life. Thou shall not steal is the right to own property, and so on and so forth. We must not forget that Judaism gave the world the concept of human rights..$^{14}$

\footnotetext{
12 Yubaraj Sangroula, Concepts and Evolution of Human Rights: Nepalese Perspective (2005).

13 IshaY, supra note 1.

14 Id.
} 
It could be a coincidence that Cassin was a Jew and that he emphasised Judaism, but at the same time, he maintained that Christianity and Islam are also the significant fundamentals.

Ironically, some scholarly writings show that the sanctimonious oriental values were understood and even transplanted into the Western world. C.H. Alexandrowicz, an acclaimed historian of the law of nations, explained the significant contribution of the Asian countries in the early sixteenth, seventeenth and eighteenth centuries by stating, " $[\mathrm{t}]$ he European agencies in the East learned the lesson of coexistence of Hinduism, Islam, and Christianity in India (particularly on the west coast) and transplanted their experience to the West, which had been so long incapable of extricating itself from the obsession of religious wars.'.15

\section{Brief History of Human Rights in Asian Societies}

This article looks to understand the significance of custom and proposition of Eastern values generally from the religious institution which shaped the way of life of people. As clarified, religious preaching is not a supernatural understanding but tries to understand the very nature of human action and considers the action appropriate and acceptable for a common good. In this view, it is important to analyse philosophy and human rights within such distinct understandings.

Scholars like Matthew A. Ritter has justified Judeo-Christian heritage as a predecessor of modern human rights. However, he has conveniently equated Judeo-Christianity with the West and forgot to mention the Eastern origin of Judeo-Christian heritage. He has analysed meticulously the tenets of Judeo-Christian heritage and convincingly showed that the Judeo-Christian religion comes closer to modern human rights. ${ }^{16}$ This article will discuss three major religions: Buddhism, Islam and Hinduism. This article will not discuss Judeo-Christian heritage despite the fact that Judaism and Christianity are Eastern religions because many scholarly works justify the tenets of Judaism

\footnotetext{
15 C.H. Alexandrowicz, The law of Nations in Global History 45 (David Armitage \& Jennifer Pitts eds., 2017); Reynaldo Galindo Pohl (Special Representative on the Human Rights Situation in the Islamic Republic of Iran), Rep. on the Human Rights Situation in the Islamic Republic of Iran, U.N. Doc. E/CN.4/1987/23 (Jan. 28, 1987).

16 Matthew A. Ritter, Human Rights: The Universalist Controversy. A Response to Are the Principles of Human Rights "Western" Ideas? An Analysis of the Claim of the "Asian" Concept of Human Rights from the Perspectives of Hinduism, by Dr. Surya P. Subedi., 3 O CALIF ORNIA Western International LaW Journal 71 (1999).
} 
and Christianity as a predecessor of modern human rights, but all these works are done keeping in mind that they are Western religions. This article at the outset has mentioned that the Judeo-Christian religion is as Eastern as other major religions. Therefore, any justification with regards to the Judeo-Christian religion is an advancement of Eastern discourse.

\section{$4 \quad$ Buddhism}

Buddhism was introduced in a caste-stratified society which contradicted its basic tenet of being equal in an absolute sense. Hence, Buddhist moral teachings substantially contained many precepts of duties and rights. The doctrine of 'ahimsa' in Buddhism elucidates the view that every individual respects the inherent dignity of their own life, furthering love and protection to others in a selfless manner, and does not deserve the suffering which is extended to others.

In Buddhist philosophy, the cycle of rebirth that serves as a justification for the basis of the individual's existence indicates that everyone is related and connected in a universal manner and cannot exist independent of each other. Hence, the actions of a single individual affect the rest. The Dalai Lama, considered to be the reincarnation of Bodhisattva of Compassion and the spiritual leader of the 'Gelug School' of Tibetan Buddhism, has stated that there exists a universal responsibility to promote human survival. He has reiterated the inseparable link that exists between the human heart and the environment that needs to be fostered through love and understanding. He delivered an address to a Conference on Human Rights organised by the UN in Vienna, where he highlighted the Buddhist approach to human rights. ${ }^{17}$

It is argued that there are non-Western ethical traditions that can espouse human rights, such as Theravāda Buddhism. Human rights can be deduced from Buddhist moral teachings by assessing the association between the Buddhist precepts and social justice as seen in the Theravāda tradition. Concerns regarding 'self-fulfilment, respect for others and the quest to contribute to others' have been found in Confucian, Hindu and Buddhist traditions, hence implying correlative duties for a just and peaceful society. Hesanmi expounded the reasonability of affirming the mutual entailment of rights and duties rather than erecting a false dichotomy between the two. ${ }^{18}$

17 Daisaku Ikedia, A Forum for Peace: Daisaku Ikeda's Proposals to the U.N. (Olivier Urbain ed., 2014).

18 Andrew Clapham, Human Rights: A Very Short Introduction 5 (2nd ed. 2015). 
Ananda Gurugé notes that "Professor Perera demonstrates that every single Article of the Universal Declaration of Human Rights, even the labour rights to fair wages, leisure and welfare has been adumbrated, cogently upheld and meaningfully incorporated in an overall view of life and society by the Buddha". 19

Kenneth Inada has suggested a definitive foundation for human rights in Buddhist metaphysics. In a discussion of 'The Buddhist Perspective on Human Rights', Inada refers to 'an intimate and vital relationship of the Buddhist norm or Dhamma with that of human rights. ${ }^{20}$

The Buddhist virtue of compassion emboldens us to develop the human capacity for empathy to the extent as to relate completely with the suffering of others. Several texts elucidate the process of exchanging self and other and suggest a meditative ritual where we imagine ourselves in the other's position. This is referred to as sentimentalism in the West, which emphasises the role of the emotions in moral judgments. According to this perspective, the ascription of human rights is 'an expression of a deep human ability to recognize the other as like oneself; to experience empathy for the other's needs and sufferings; to consent to, support, and rejoice in the fulfilment of the other's human capacities and well-being. ${ }^{21}$

It's stated in orthodox Buddhist teachings that torture or killing that is classified as abuses of human rights will induce negative karmic consequences. Karma, which is the law of causation, has an ontological foundation in natural law resembling physical laws that dictate biological growth or heat. It has been suggested that the concept of human dignity can be derived from doctrines of a Buddhist nature. While the contemporary idea of human rights has a distinguished cultural origin, its basic preoccupation with human good is experienced by Buddhism.

The followers of Buddhism in the contemporary age have founded the Soka Gakkai International (SGI), a community-based Buddhist organization that promotes peace, culture and education based on the inherent dignity of life by upholding and propagating Nichiren Daishonin's Buddhism.

\footnotetext{
19 L.P.N. Perera, Buddhism and Human Rights: A Buddhist Commentary on the Universal Declaration of Human Rights Xi (1991).

$20 \quad$ Kenneth K. Inada, The Buddhist Perspective on Human Rights, in Human Rights in Religious Traditions 71 (Arlene Swindler ed., 1982).

21 L.S. Cahill, Rights as Religious or Secular: Why Not Both?, 14 Journal of LAW AND RELIGION 45 (1999); Yoichi Kawada, The Buddhist Perspective of Life and the Idea of Human Rights, 21 Journal of Oriental Studies 123, http://www.iop.or.jp/Documents/1121/ Journal21_Y.Kawada2.pdf.
} 
The Lotus Sutra, which expounds the essence of Buddhist teachings was founded 80 years ago was initially dismissed as a congregation of sick and poor in Japan. However, the members took this as a badge of the highest honour and resonating with a burning conviction undertook the work of engaging in dialogue with people in order to encourage and nurture hope. ${ }^{22}$

It believes that 'the inherent role of religion can be defined as taking human hearts that are divided and connecting them through a universal human spirit. It is the religion that supports, inspires and provides an impetus for people searching for the good and the valuable in their lives. ${ }^{23}$

The Universal Declaration of Human Rights claims that human rights addresses the relationship between society and individuals, safeguarding the latter from exploitation and persecution, with its aim being legal in nature. It is expected by Western ideologists that clauses which refer to equal treatment and dignity of life should be universally applicable. There is a valid consensus among the scholars that these universal rights are congenial with Buddhist morality. ${ }^{24}$

Islam originated in Mecca and Medina of Saudi Arabia in the early seventh century and since then gradually spread all over central and southeast Asia as well as Africa via trade and commerce. Since the time of Mohammad when it first originated, Islam had championed for human rights such as the right to life, right to freedom of expression, right to equality before the law, rights of women and as such. One might even argue that Islam has not only advocated for the human rights that are contained in the present-day human rights instruments such as the Universal Declaration of Human Rights but went beyond that and ensured more human rights such as the rights of parents as well as children, rights of neighbours, inheritance and other rights which are not mentioned in modern human rights documents and all these developments took place in Asia through Islam, centuries before the West came up with the modern notion of human rights.

\footnotetext{
22 IKEDA, supra note 17.

23 Id. at 259.

24 Andrew May, Buddhism and Human Rights: A Book Review, Andrew-May.com (2001), http://www.andrewmay.com/bhr.htm.
} 
Islam preaches the right to life of every human being. ${ }^{25}$ With regard to when taking of a life is justified, it is mandated that even when someone is guilty of murder or spreading corruption on the earth, such can only be decided only by a proper and competent court of law. Even when there is any war with any country, only by the decision of a properly established government can a life be taken away. In fact, no human being has the right by himself to take a human life without any reason, and even when such retaliation is justified, due process must be followed. If anyone, however, murders a human being, it would be as if he has slain the entire human race.

In another place, the Holy Qur'an also distinguished homicide from that of destruction of life for justified reasons by ordering the Muslims not to kill any human being (herein referred as soul) without following due process of law, because Allah has made all human life sacred (6:151). Prophet Mohammad has also referred to murder as the greatest sin besides associating something with God. All these instances strengthen the fact of how strongly Islam strives to respect the right to life of every human being.

Immediately after mentioning the right to life, the Holy Qur'an addresses the right to the safety of life of human beings. ${ }^{26}$ The Holy Qur'an lays down that whenever someone saves the life of another human being, it would be deemed as if she had saved the entire humankind. This saving can be interpreted to mean diverse situations. If someone is ill or wounded and in need of help, it is the duty of everyone to help that man irrespective of his race, gender, skin colour, nationality or belief. If someone is dying of starvation, every Muslim is obligated to feed him. ${ }^{27}$ Therefore, Islam strives to ensure the safety of the life of every human being on earth without any discrimination.

Islam does not solely depend on voluntary help and charity. Rather, Islam had made charity compulsory to the rich through a practice known as zakat to help poor people obtain the basic necessities of life. ${ }^{28}$ In fact, according to Al-Bukhari, the Prophet has clearly stated that this portion of the wealth over which the poor and needy have claim will be taken from the wealth of the rich and then be given to those in need. Islam has forbidden the primitive practice of capturing a free man and making him a slave or selling him into slavery. In this regard, the Prophet Mohammad clearly stated that he shall stand as a plaintiff against three categories of people, slavers being one of them. Moreover, this injunction is general in nature and applies to every human being regardless

25 Syed Abul A'la Maudoodi, Human Rights in Islam (2nd ed. 1981).
26 Id. at 1.
27 Id.
28 Id. 
of their nationality, race or belief. Islam also gives protection against arbitral arrest. According to Caliph Umar, "no one can be imprisoned for any other purpose except for the pursuance of justice in Islam". ${ }^{29}$ Therefore, in Islam, every human being is considered to be innocent until proven guilty, and even when justice is served, it must be in accordance with due process of law.

In Islam, all human beings are equal before God regardless of where they were born, their social position, their race, colour or gender. The Holy Qur'an mandates, 'O mankind! We have created you from a male and a female'.30 Therefore, in Islam, all men are considered to be brothers as they are the descendants from one father and mother. ${ }^{31}$

There are other rights prescribed by Islam which can be found mandated in the Holy Qur'an and in the recording of the words and conduct of the Prophet, as well as his 'Sahabi', also known as Hadith. Some other rights as incorporated and practiced in Asia through Islam are the right to freedom of association, the right to religion, the right to take part in the affairs of the State, the right to freedom of conscience and conviction and as such.

\section{$6 \quad$ Hinduism}

The present notion of human rights is based on universal values found in all major civilisations of the world: In Asia, Africa and of course, in Europe. One such instance is the reflection of human rights in Hinduism which was practiced in ancient Asia. Secularism in the conduct of the domestic and international affairs of the state, equality of all human beings and adherence to the principle of peaceful co-existence, regardless of faith and beliefs were some of the core elements that can be found deeply-rooted in ancient Hinduism. Though the Hindu approach towards human rights has changed drastically since the Dark Age, the ancient Hindu scriptures from which the religion originated from only contain the principles of universal fraternity, peaceful coexistence and the equality of all human souls.

A significant reflection of modern constitutional monarchy can be deemed in the writings of Kautilya which stated that '[i]n the happiness of his subjects lies [the king's] happiness; in their welfare his welfare. He shall not consider as good only that which pleases him but treat as beneficial to him whatever

29 Farhad Malekian, Principles of Islamic International Criminal law: A Comparative SEARCH 375 n. 1 (2011).

30 Qu'ran 49:13 (Mohsin Khan).

31 MaUdoodi, supra note 25. 
pleases his subjects. ${ }^{32}$ Here, Kautilya was stating a king's obligation to follow an order based on dharma. Furthermore, the scripture also attaches some qualification on the king himself such as: The king must be a dharmic person (one who follows dharma), always be responsive to what the wishes of his people are and lastly, he must be guided by the sound advice of the elder statesmen of society when making decisions about the affairs of the State.

With regards to how a dispute should be resolved, Kautilya mandates that such disputes are to be judged in accordance with four bases of justice, namely-Dharma (based on truth), evidence (based on witness), custom (based on the tradition accepted by the people) and lastly, royal edicts (based on law as promulgated). ${ }^{33}$ The concept of right and wrong in Hinduism is contained in a collection of sacred scriptures and divine revelations such as the four Vedas $^{34}$ and Dharma sastras. These scriptures include the 108 Upanishads, ${ }^{35}$ the 18 Puranas, ${ }^{36}$ the 100 Up-Puranas and a number of Smritis. ${ }^{37}$ The Vedic texts reflect how peaceful and orderly people engaged in the fulfilment of their lives in accordance with Rita are. ${ }^{38}$ These scriptures are evidence that peace, justice, rights and wrong were concepts introduced through Hinduism long before they were in the West.

The very notion of dharma alone contains many facets of the modern principles of human rights. The word dharma originated from the verbal root $d h r$, which means to uphold or to maintain the law and order or eternal order of the world.$^{39}$ All the dharmas, though articulated in different senses, refer to obligations that must be fulfilled to maintain and support the individual, the family, social class and the whole society. ${ }^{40}$ In fact, the various dharmas are simply different rules of action one must apply to different stages of life, different social class, to being a king or a human being and so on.

On the other hand, dharma used in a legal sense 'refers to the laws and traditions governing society, informing every citizen of the rules governing

\footnotetext{
32 Kautilya, The Arthashastra 125 (L.N. Rangarajan trans., 1992) (1987).

$33 \quad I d$. at 351.

34 Advaita Ashrama, The Brhadaranyaka Upanisad: With the Commentary of SANKARACARYa (Swami Madhavananda trans., 3rd ed. 1950).

35 Hindu Scriptures (Robert Charles Zaehner trans., 1966).

36 Upendra Nath Ghoshal, A History of Indian Political Ideas: The Ancient Period and the Period of Transition to the Middle Ages 580 (1959).

37 Id. at 8.

38 Pratima Bowes, The Hindu Religious tradition: A Philosophical АррвоACH (1976).

39 Subedi, supra note 3.

40 John M. Koller, The Indian Way 62 (1982).
} 
social life. ${ }^{41}$ According to Kollar, 'dharma is usually classified according to the requirements of one's position in society and stage in life, for these represent the main factors of time, place and circumstance that determine one's own specific dharma' ${ }^{42}$ Ariel Glucklich similarly stated that 'Dharma is not a what, it is how: there is the dharma of conduct, of course, and this we usually understand as law and morality.43 Dharma is the concept of righteousness which is used to regulate the relationship between individual, family, community and the State.

In its original sense, dharma implies the maintenance of peace and security through the rule of law and order within a larger cosmic framework. Therefore, perceived this way, the concept of dharma seems to be secular and universal in nature and has little to no connection with the various Hindu gods and goddesses. In fact, Eyffinger rightly states that 'indeed a quite unique characteristic of ancient Indian thinking with respect to international relations was its insistence on universalism. This notion had religious as well as political connotations, as is illustrated by the postulated universality of the individual soul. In political theory, this concept was exemplified by a view of world government based on non-violence towards all creation and the indiscriminate quality of mankind. With regard to inter-state conduct, no distinction was recognized between believers and non-believers. ${ }^{44}$

Since the advent of Hindu philosophy, the religion has championed the idea of harmony and fraternity among all individuals and the quality of human beings, regardless of any factors such as belief, gender, race or colour which are the main cause of discrimination even in the twenty-first century. Indeed, it was this non-discriminatory, universalist culture of ancient India and Southeast Asia which made it possible for the European traders to establish trade with this region of the world on equal terms with that of the natives. These traders entered into various treaty relations with these Asian States as equal partners and received the benefits of the region's rich system of trade and commerce. During those earlier periods, there existed no issues of inferior or superior civilization, and commercial relations between European States and Asian States were free from religious bias.

With regard to secularism and peaceful co-existence, Arthasastra contains several mandates which only strengthen the fact that secularism in the

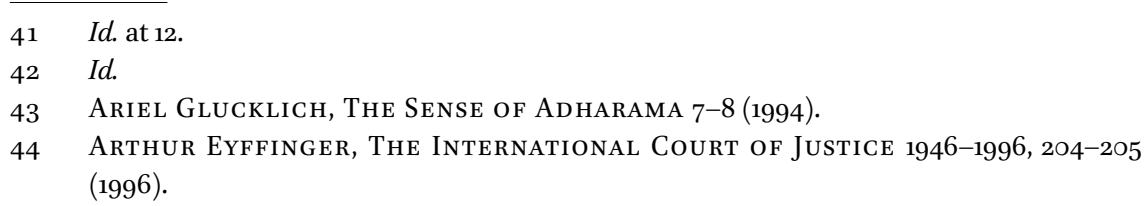


governance of State affairs, universalism with regard to human approaches to the outside world and the principle of peaceful co-existence when dealing with foreign powers of different faiths and beliefs, were some key elements which were embedded in ancient Hinduism. Alexandrowicz opined that:

Arthasastra constitutes a divorce of politics (internal and external) from moral philosophy and creates a dichotomy typical of Brahmin learning which contrasted sharply with the Buddhist concept of the supremacy of moral law over and above politics. In terms of European philosophy, it might be comparable with the efforts of those theologians and lawyers who tried to extricate the jusgentium from the grip of theology. ${ }^{45}$

This gives a genuine outlook to the statement that the concept of human rights was well entrenched in the all major beliefs of oriental philosophy. The means to suggest to the people their obligation to perform obedience for human rights is governed from general stories and, if observed, serves a general utilitarian purpose so that people can understand and adapt to practices without having to deal with complex ideas. This is largely significant when addressing a large portion of society rather than only understanding it as mythical beliefs. The concept of human rights is incorporated in every sector and walks of life. It is more important that the understanding of such concept is based on acknowledging the capacity of each person to perform such acts.

\section{$7 \quad$ Asian Countries in Development and Origin of Human Rights}

We have had a distinct observation on various understanding of oriental perspective. The theoretical clarity remained, however, ineffective in the implementation and practice of such customs, even more when economic development could not serve the people's needs. In the current situation, a homogeneous view of Asian society reflects that particular groups which are the governing elites that receive global recognition. To this effect, Asian societies have also been willing to accept democracy more openly than the past. From the mid-twentieth century, political systems lacked the openness and democratic nature which justified authoritarianism and incidental suppression. States understood necessities of democratic institutions and therefore,

45 Charles Henry Alexandrowicz, An Introduction to the History of the LaW of Nations in the Nations in the EAst Indies: (16TH, 17TH AND 18TH Centuries) (1967). 
prioritised their effort on establishing such norms. The Bangkok Declaration, which was ratified by all the Asian governments at the 1993 Asian regional preparatory meeting for the Vienna World Conference on Human Rights, remains a relevant example and many of these Asian governments have solid engagements with regard to human rights. Their commitment is admirable. One illustration is India who, along with other States, is pledged to human rights through its constitutional apparatus with an independent and robust judiciary and in spite of several disputes and complications, has tried to sustain the struggle for human rights. ${ }^{46}$

Asia has had a long humanist culture whose progression is associated with the formation of norms of behaviour based on consideration and appreciation for human decency and morality throughout the world. Philosophical discourses found in religious mythologies such as Mahabharata or rules and customs that maintain rights for the most defenceless groups or individuals were included in the Hammurabi Code, the Laws of Manu, the conventions of Empress Jingu and the writings of Sima Qian and Confucius. ${ }^{47}$

In India, there have been instances of jurisprudence principles since around 4000 B.C. that included descriptions of rules and procedures for civil and criminal cases, specifically concentrating on punishment. The Vedic Rishis always urged for the protection of everyone in society, and this was considered as the duty of the State or king. Hence, the premise of the rights of individuals is not entirely a Western concept. ${ }^{48}$

The Rig Veda also alludes to three types of civil rights: Tana (body), Skridhi (dwelling place) and Jibhasi (life). In the book 'Hindu Narratives and Human Rights', the author explicates that the Hindu texts include a comprehensive and intricate analysis of 'the particular and universal dimension' on human rights. It involves an examination of the questions that Draupadi asked in the Mahabharata after she was coerced to attend the assembly of Kauravas. The author also claims that the conflict between Kauravas and the Pandavas, with the issue being ownership of land, is also one of, 'the contested rights'. The prevalence of Indian literature which includes both short and long narratives like Mahabharata, Ramayana, Panchantantra, Bhagwad Gita, etc. presents the debate on human rights in the manner of folk tales and stories. These anecdotes have been investigated by the author who assert that Indian thinkers

46 Yash Ghai, Human Rights and Governance: The Asia Debate, 15 Australian Year Book OF INTERNATIONAL LAW 1 (1994).

47 Int'l Fed'n for Human Rights, Demystifying Human Rights Protection IN ASIA (2015), https://www.burmalibrary.org/docs21/FIDH-2015-Demystifying_Human_ Rights_Protection_in_Asia-red.pdf.

48 Giriraj Shah \& K.N. Gupta, Human Rights: Free and Equal (2001). 
not only championed for human rights but also exhibited that the violation of such rights may have ramifications that 'extend beyond the individual' 49

The Mahabharata is customarily classified as an archaic oral Indian epic which incorporates many significant systems of codes, values and narratives for Indians to contemplate on human destinies, births and deaths, the futility of war, the nature of divinities, the ambiguous nature of human action and unavoidable consequences of individual actions. ${ }^{50}$

Hinduism itself had some core values which protected and promoted human rights. Those rights never came from the West. Hinduism originated from and was developed in the Indian sub-continent, which proves that human rights existed in this region from the very beginning. In fact, the concept of non-discrimination between believers and non-believers originated in India 2000 years ago. ${ }^{51}$ Moreover, King Ashoka, after the Kalinga War (261 B.C.), proclaimed universal peace and respect for the rights of others in the following words: 'His Sacred Majesty Ashoka desires that all living beings should have security of existence for which men should exercise self-control and not to take by force what others possess. All should enjoy peace of mind by co-existence and not by mutual interference and recrimination'. ${ }^{52}$

Even before the Universal Declaration of Human Rights, during the colonial period, Raja Ram Mohan Roy, the father of Indian Renaissance, fought against the age-old system of Sati (burning of widows in her dead husband's funeral pyre). With his active persuasion, Lord William Bentick, the thenGovernor General of British India, passed the famous Regulation XVII in 1829 that declared Sati as illegal and punishable by courts. ${ }^{53}$ Even though the British claim it as a Western contribution, as the Act was passed by Lord Bentick, it was Raja Ram Mohan Roy who actively raised his voice against it and brought it to the attention of the authorities. Despite many challenges, he made it possible and abolished the Sati system because it was a huge violation of right to life. He also condemned polygamy, denounced the caste system, advocated for the right of Hindu widows to remarry, etc.

49 Ashok Vohra, Discourse on Human Rights, The Tribune (May 16, 2010), https://www .tribuneindia.com/2010/20100516/spectrum/bookı.htm (reviewing ARvind SHARMA, Hindu Narratives on Human Rights (2009)).

50 M.D. Muthukumaraswamy, Mahabharata: Texts and Performances (2017).

51 Nagendra Singh, History of the Law of Nations Regional Developments: South and South-East Asia, in Rudolf Bernhardt, Encyclopaedia of International LaW 237, 239 (1984).

$52 \quad I d$. at 241.

53 Priya Soman, Role of Raja Ram Mohan Roy and the Abolition of Sati System in India - A Study, 7 International Journal of Development Research 14465, 14466 (2017). 
Carrying this legacy, it was Ishwar Chandra Vidyasagar, a great academician, scholar and social reformer during the colonial period, who championed for women's rights and was the first to marry his son with a widow, which was strictly condemned in Indian society. After the abolition of Sati, widows were treated in the society like inferior human beings and were looked down upon by the entire society. Ishwar Chandra was the first to point out their equal rights as human beings and raised the issue of widow remarriage. It was an unimaginable proposal back then. However, because of his contribution towards such issues, the Widow Remarriage Act was passed in 1856 , making the marriage of widows legal. ${ }^{54}$ Therefore, it not only became a practice in the Indian society, but it also turned into a complete law which strengthened the basis of the practice through the formal legal system.

Another ancient source of human rights is Babylonian Law, also known as Hammurabi's Code, which was a set of laws and rules formulated by King Hammurabi. It encompassed the concept of fair wages, extended protection of property and prescribed charges to be heard and proved at trial. ${ }^{55}$

The Hammurabi Code was written in systematic categories of columns and paragraphs which consisted of nearly 300 separate provisions of commercial, criminal and civil law covering contracts, judicial procedures, penalties or punishments, including nature of crimes, family relationships, inheritance and specific aspects of human rights. The Code contains original examples of the right to freedom of speech, presumption of innocence, the right to present evidence and the right to a fair trial by judges. It also postulated protections for different classes of Babylonian society, including women, widows, orphans, the poor and even the slaves. The most important contribution of the Code is the enactment of a vital principle of the rule of law which stated that few laws are so crucial that they apply to every individual, including the king (State). This has cultivated an essential issue for human rights which is reflected in the association between duties and rights. There are duties that exist which everyone is beholden to, but, if they remain unperformed, others would have a right to claim them. ${ }^{56}$

The precepts of Islam which were made clear 500 years later and were acknowledged in the writings of the prophet Muhammad also emphasize the

54 Ramandeep Kaur, Ishwar Chandra Vidyasagar - A Great Reformer, My India (Sept. 25, 2019), https://www.mapsofindia.com/my-india/history/ishwar-chandra-vidyasagar-a -great-reformer. Pravin H. Parekh, Human Rights Year Book 2010 (2010).

56 Paul G. Lauren, The Foundations of Justice and Human Rights in Early Legal Texts and Thought, in The Oxford Handbook of International Human Rights LaW 163 (2013). 
responsibility or duty ( jard) to protect the well-being of others. It underscores a command to safeguard the weakest members of society and to perform charity. The Holy Qur'an covers topics ranging from social justice, the sanctity of life, personal safety, mercy, compassion to respect for every individual. Islam also realized an affiliation between religious beliefs and the law of a political community. The Constitution of Medina, which was written to administer the first Islamic State, approached matters of freedom and injustices resulting from additional privileges due to a hierarchical tyrannical distinction and provided a buffer for individuals by including provisions concerning religious tolerance. ${ }^{57}$

Muhammad Ali Zinnah stated in his speech to the first constituent Assembly of Pakistan on September 11, 1947 that:

You are free to go to your temples; you are free to go to your mosques or to any other place of worship in this state of Pakistan. You may belong to any religion or caste or creed-that has nothing to do with the business of the state. We are starting with this fundamental principle that we are all citizens and equal citizens of one State. ${ }^{58}$

In China, there were several philosophers who advanced their ideas regarding justice and human rights. Mo Tzu (c. 470-391 B.C.) established the Mohist school of moral philosophy. During his time, there was constant warfare, violence and widespread abuse; he denounced acts that were harmful to others such as hierarchies and divisions in society that prescribed varying treatment and any instance where the powerful suppressed the weak.

He set, as guiding principles, the notion of self-sacrifice, the institution of uniform moral standards and the discharge of responsibilities for others' security. MengZi (372-289 B.C.), also known as Mencius, stated that every individual inherently shares a common humanity, moral worth, dignity and goodness and is able to empathize. He believed that it is the duty of governments to foster these qualities. He insisted that rulers or kings who indulged in oppression and persecution lost the 'Mandate of Heaven', relinquishing the authority to rule. ${ }^{59}$

There are several notable leaders who have expounded Buddhism and expressed concerns about socio-political issues in the context of human rights like Aung San Suu Kyi, A.T. Ariyaratne, Maha Ghosananda and Sulak Sivaraksa.

Ann E. Mayer, Islam and Human Rights (5th ed. 2012).

$5^{8}$ Subedi, supra note 3 .

59 Wm. T. debary \& Weiming Tu, Confucianism and Human Rights (1998). 
There have also been institutions established by Buddhists to promote human rights including the Cambodian Institute of Human Rights, the Tibetan Centre for Human Rights and Democracy and the Thai National Human Rights Commission. Several Asian countries with large Buddhist populations (Thailand, Myanmar, Laos, Cambodia and Vietnam) are also members of the ASEAN Intergovernmental Commission on Human Rights (AICHR) founded in $2009 .{ }^{60}$

\section{8}

\section{Conclusion}

Hence, the concept of human rights, mainly a post-World War II concept, developed largely during the formative years of the United Nations (UN) by Western countries. Even though there is no other option other than to agreeing that the East does not have sufficient evidence or literature to establish that human rights existed in this region prior to the establishment of the UN, merely accepting human rights as a Western concept for the sole reason stated above is to ignore the practices of other great ancient civilizations of the world. This clearly undermines the existence and practice of human rights in the Asian region. Due to the denial of scholars and academicians of the West, who mostly dominated the legal literature, that this notion that human rights is a Western concept has now been wrongly established, whereas the trend of human rights practice and development was in existence in Asia much before it was even thought of by the West.

It is true that human rights norms have not been guaranteed to the people in large sections of Asian societies. However, certain generations of poverty cannot wipe out the positive aspect a society possesses. Eastern philosophy, in its distinct and very similar connotation as highlighted, has brought appropriate, generalized and existing concepts of welfare and security. It is true that there is not much clarity regarding the democratic foundation of the State practice. However, States are realizing the importance of such institution to ensure that people's human rights are upheld and to avoid anarchy. It can be observed that isolated communities forced into a consumer market requires time to adapt and manifest its values and tradition. Therefore, not merely taking it as a hostile situation, Western States should avoid the tendency to compare the nature and concept of human rights in binary opposites.

6o Damien V. Keown, Are There "Human Rights" in Buddhism?, 2 Journal of Buddhist Ethics 3 (1995). 
The tendency of the colonial power to wrongfully undertake communities, other than Western communities, as uncivilized should not be practiced. Therefore, the concept of Asian societies and Eastern philosophy should be recognised. The development of human rights and the inclusion of the concept of human rights should not be under the veil of mythical or primitive perspective. Rather than analyses of concepts such as mutual cohesion and equality which was effectively practiced, the concept of human rights should be extensively reviewed and included to maintain a better framework of human rights for all. 